\title{
FOREWORD
}

\section{Reagan in the World}

William Inboden

We appear to be at the outset of a very fruitful period of scholarship on the Ronald Reagan administration and international politics in the 1980s. This volume exemplifies this new era and establishes many of the parameters of future lines of inquiry into this most consequential of presidencies and most consequential of decades. It began as a three-day conference convened in January 2017 at the University of Texas at Austin by the Clements Center for National Security, with generous additional support provided by other University of Texas at Austin entities, including the Robert S. Strauss Center for International Security and Law, the Lyndon B. Johnson School of Public Affairs, and the Departments of History and Government, as well as Southern Methodist University’s Center for Presidential History. The editors Jonathan Hunt and Simon Miles merit special commendation for their intellectual vision, indefatigable labor, grit, and good cheer in designing the conference and then refining its most trenchant findings into this book. Its chapters represent a broad array of fresh insights into and perspectives on the foreign and defense policies of the Reagan administration and their manifestations around the world.

Four reasons in particular illuminate why the present moment marks the beginnings of an ideal period for scholars to study the Reagan presidency, all of which are evidenced by the chapters in this book. First, recent years have brought an abundance of newly declassified archives documenting the deliberations, policy developments, and decisions made by the Reagan administration. While scholars in previous years had to rely disproportionately on journalistic accounts and memoirs, these new primary sources provide fresh new insights into the administration's policymaking. When combined with the openings of many additional archives overseas, these new collections provide a further global perspective on the policies of other nations and their perspective on the United States. Second, the Reagan presidency was recent enough that many of its main policymakers are still alive and available to be interviewed, offering their firsthand accounts of the policies and events of the time. Third, now that three decades have passed since Reagan left office, 
sufficient time has elapsed for us to engage in retrospective assessment. Simply put, we now know how many of the stories ended—or at least have the historical and global context to draw provisional conclusions about the consequences of Reagan administration policies toward the Soviet Union, nuclear weapons, Asia, Latin America, the Middle East, terrorism, international economics, and many other issues. Fourth, a new generation of scholars has come of age since the Reagan presidency ended and thus have been spared the partisan fevers that sometimes beset Reagan's apologists and detractors while he was in office. Even in hindsight such passions sometimes can cloud the objectivity of older historians who have firsthand memories of the Reagan years; younger scholars are generally immune to such intellectual afflictions. It is perhaps no coincidence that the preponderance of chapters in this book are penned by a new generation of historians.

While no single collection can provide a definitive account of any presidency, this volume covers a capacious array of themes and will be of value to all future scholars studying Reagan administration foreign policy. In particular this book highlights the interplay between US domestic politics, US foreign policy, and international history; explores the relationship between economic trends and grand strategy; suggests ways to think about human rights in relation to soft and hard power, including the Reagan doctrine; illuminates the importance of the Cold War relative to other consequential concurrent trends such as the limited reform and opening up of China or the broader transformations in international markets and the information revolution; and, most fundamentally, considers the extent to which Reagan did or did not change the material and symbolic bases of American power in the world.

As the twenty-first century unfolds, it becomes surpassingly clear that many of the global issues and policy challenges shaping the current era-such as terrorism, great power competitions in Europe and Asia, political ferment in Latin America, Africa, and the Middle East, shifts and strains in alliances, globalization and communications revolutions, energy competition, and economic growth and inequality - trace their roots to the 1980s. We cannot understand our contemporary moment without understanding the Reagan administration and its tumultuous decade. This book is indispensable for doing so. 
THE REAGAN MOMENT 
